\title{
ACCESS OF BARE NECESSITIES: A COMPARATIVE ANALYSIS OF SANGLI DISTRICT, MAHARASHTRA
}

\author{
${ }^{1}$ Dr. Nanaware Dada Ramdas, ${ }^{2}$ Kumbhar Ajay Dattu \\ ${ }^{1}$ Assistant Professor, Deccan Education Society, Pune, Chintamanrao College of Commerce, \\ Sangli - $416415(\mathrm{MH})$ \\ ${ }^{2}$ Research Scholar, Department of Economics, Shivaji University, Vidyanagar, \\ Kolhapur, - 416004 (MH)
}

Article DOI: https://doi.org/10.36713/epra7520 DOI No: 10.36713/epra7520

\begin{abstract}
-
The present study examines that the sectorial inequalities in access of bare necessities to the people by the Bare Necessitates Index (BNI) of Sangli district at the tehsil level along with the sector. This is an innovative study for the Sangli district and it covered all ten tehsils along with sectorial i.e., rural and urban to the grassroots level analysis of BNI. The estimation of the Bare Necessitates Index (BNI) of the Sangli district is based on Census 2011 data. Main observations of this study, the BNI of Shirala and Walwa total, rural and urban has a high category, it all indicates that the better access of basic/bare necessities to total, rural and urban people. Overall estimation of Bare Necessities Index (BNI) of Sangli district total, rural as well as urban has a very low category. It treated access of bare necessities to total, rural as well as urban people are very low in Sangli district. Sectoral analysis of BNI indicates that the access of bare necessities to rural people is very low than urban people in Sangli district.
\end{abstract}

KEYWORDS: BNI, Water Index, Sanitation Index, Housing Index, Micro-Environment Index, Other Facilities Index.

\section{INTRODUCTION}

Sangli is a district of Maharashtra that is located in the south and southeast it covers an area of approximately 8,572 square feet. Geographically Sangli district is western portion and mountainous as well as economically and socially is diverse. Sangli district has a diverse range of vegetation and animals, graphs and sugarcane, among other commodities are the proof of identification mark of the Sangli district and its agro-ecological situation and productivity. Sangli district is one of an important part of Maharashtra state, its total population size is 28.2 lakhs includes the male population is 14.3 lakhs and females 13.8 lakhs. The sex ratio of the district is 966 and overall literacy rate is $82.4 \%$ and the density of population is 330 per sq. $\mathrm{km}$. [1, 2]

The Bare Necessities Index is a newly introduced by the Ministry of Finance and Statistics, Government of India, to assess the access of bare necessities to people at local to global level. The concept of Bare Necessities Index is firstly introduced in the Economic Survey of India report, 2020-21. It is a composite statistic of various bare necessities i.e., clean water, sanitation, housing, micro-environment and other facilities, etc. which needed for everyone to sustain their life. The main goal of Bare Necessities Index is that to observe access to the bare necessities like housing, water, sanitation, electricity and clean cooking fuel which is essential to live a decent life. This research study examines the progress made in providing access to bare necessities by constructing Bare Necessities Index (BNI) at the rural, urban and each tehsils level in Sangli district. The BNI estimation summarizes 21 sub- indicators includes 16 positive and 5 negative sub-indicators of 5 main dimensions i.e., water, sanitation, housing, micro-environment, and other facilities. [3, 4] The BNI has been created for all tehsils at total, rural and urban base as well as overall Sangli district using Census data of Sangli district 2011 data. The Bare Necessities Index exercise of Sangli district has examined that the tehsils and sectorial i.e., ruralurban-based overall access of bare necessities to the people and their inequalities. 


\section{OBJECTIVES}

The major objectives of this study are as -

(i) To analyze Bare Necessities Index of Sangli district.

(ii) To analyses sectorial i.e., rural and urban inequalities in Bare Necessities Index of Sangli district.

(iii) To suggest measures for improvement if necessary, for the study area.

\section{RESEARCH METHODOLOGY AND DATA BASE}

The present study is pioneer for study area, analytical in nature and it's based on purely secondary data and some ethical observation of the researcher. The Bear Nasserites Index (BNI) is inclusive and newly introduced approach. It mainly focuses on access of least necessities i.e., clean water, sanitation, housing, etc. which is needed to each person to sustain their life. The secondary data related to Bare Necessities dimensions; subindicators have collected from the Census of India 2011 specifically Sangli district. The methodology of create Bare Necessities Index of each tehsils rural and urban base along with overall Sangli district has adopted from socio-economic review Government of India, which was published in January, 2021. Detailed methodology, dimensions and indicators of Bare Necessities Index estimation of the present study area are as fallows.

\section{- About Indictors of BNI}

Bear Nasserites Index is summery of five main dimensions and its 21 sub-indicators statistics which related to basic necessities it needed to each people. Five main dimensions of BNI like, access of clean water, sanitation, housing, micro-environment and other facilities. There are 21 sub-indicators of the BNIs which is categorized into two categories i.e., (16) positive and (5) negative indicators. Following diagram and table shows that main dimensions, sub-indicators and its weightage of Bare Necessities Index (BNI's) are as follows- [3]

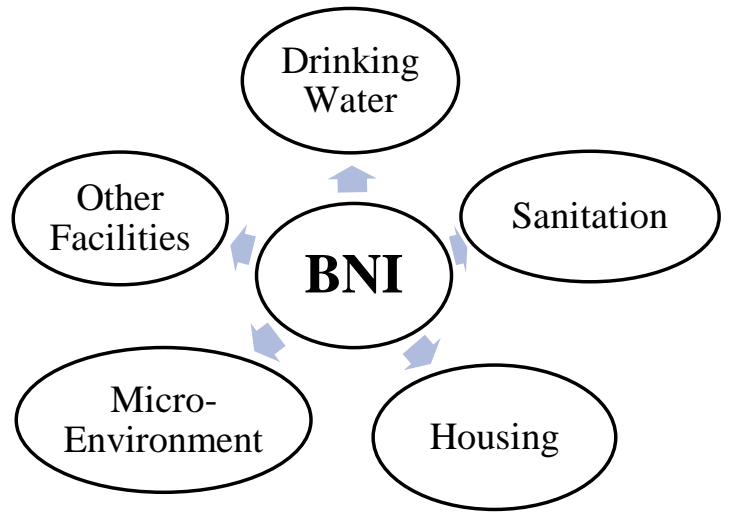

Bare Necessities Index (BNI): Dimension, Indicators, Types and Weightage

\begin{tabular}{|c|c|c|c|}
\hline Dimension & Indicator & Types & Weightage \\
\hline \multirow{5}{*}{$\begin{array}{l}\text { Water (5) } \\
\quad 1 / 5\end{array}$} & Tap-Treated & +ve & $1 / 5$ \\
\hline & Tube/Borewell & +ve & $1 / 5$ \\
\hline & Well-Covered & + ve & $1 / 5$ \\
\hline & Within dwelling & + ve & $1 / 5$ \\
\hline & Outside dwelling & -ve & $1 / 5$ \\
\hline \multirow{5}{*}{$\begin{array}{l}\text { Sanitation (5) } \\
1 / 5\end{array}$} & Access of Latrine & + ve & $1 / 5$ \\
\hline & Latrine: Piped sewer system & + ve & $1 / 5$ \\
\hline & Latrine: Septic tank & + ve & $1 / 5$ \\
\hline & Latrine: Twin leach pit & + ve & $1 / 5$ \\
\hline & Latrine: Single pit & $+\mathrm{ve}$ & $1 / 5$ \\
\hline \multirow{3}{*}{$\begin{array}{l}\text { Housing (3) } \\
\qquad 1 / 5\end{array}$} & Condition of structure: Good & $+\mathrm{ve}$ & $1 / 3$ \\
\hline & Type of the dwelling: Owned & + ve & $1 / 3$ \\
\hline & Pucca dwelling & $+\mathrm{ve}$ & $1 / 3$ \\
\hline \multirow{3}{*}{$\begin{array}{c}\text { Micro-environment (3) } \\
1 / 5\end{array}$} & No drainage & -ve & $1 / 3$ \\
\hline & Open drainage & -ve & $1 / 3$ \\
\hline & Use of Dirt Fuel for Cooking i.e., firewood, etc. & -ve & $1 / 3$ \\
\hline
\end{tabular}




\begin{tabular}{c|l|c|c}
\hline Other Facilities (5) & Access of separate kitchen & $+\mathrm{ve}$ & $1 / 5$ \\
$\mathbf{1 / 5}$ & No bathroom & $-\mathrm{ve}$ & $1 / 5$ \\
& Access of Bathroom & $+\mathrm{ve}$ & $1 / 5$ \\
& Access of electricity & $+\mathrm{ve}$ & $1 / 5$ \\
& Use of modern fuel for cooking: LPG & $+\mathrm{ve}$ & $1 / 5$ \\
\hline
\end{tabular}

Source: Economic Survey of India, 2020-21/ Bare Necessities Index

\section{- Bare Necessities Index Calculation}

The Bare Necessity Index is constructed by to step, first step is aggregating the sub-indicators and calculate each sub-indicator index for each dimension. The second step is that each dimension is aggregated using their scores calculated in step first for the Bare Necessities Index of the particular tehsils. There is the arithmetic mean is used for aggregation to each indicator and dimension. The goalpost values of each sub-indicator have fixed at minimum value is set 0 (Zero) and maximum values set is 100 (Hundred). The value of the index ranges between 0 and 1, Higher the value of the index indicates better access to the bare necessities and lower is low. Also, the Bare Necessities Index (BNI) providing access to bare necessities to the people, there are three categories of BNI i.e., above 0.700 indicates 'High' level, 0.500 to 0.700 indicates 'Medium' level and below 0.500 indicates very 'Low' level of access. The Bare Necessities Index is calculated using the formula below[3-6]

A) Indicators Index $=\frac{(\text { Actual Value }- \text { Minimum Value })}{(\text { Maximum Value }- \text { Minimum Value })}$<smiles>C[Hg]</smiles>

B) Bare Necessities Index $(\mathrm{BNI})=$

$$
\frac{\left(I_{\text {Water }}+I_{\text {Sanitation }}+I_{\text {Housing }}+I_{\text {Micro-Environment }}+I_{\text {Other Facilities }}\right)}{1 / 5}---(2)
$$

Whereas;

$$
\begin{array}{ll}
I_{\text {Water }} & =\text { Drinking Water Index } \\
I_{\text {Sanitation }} & =\text { Sanitation Index } \\
I_{\text {Housing }} & =\text { Housing Index }
\end{array}
$$

\author{
$I_{\text {Micro-Environment }}=$ Micro-Environment Index \\ $I_{\text {Other Facilities }}=$ Other Facilities Index
}

\section{Data Analysis, Discussion and Result}

This segment of this research paper highlighting on the access of basic/bare necessities to the people at tehsils with sectorial i.e., rural and urban of ten tehsils of Sangli district. Main observation at each sub-indicator and dimension wise of each tehsil has been made. The assessment of Bare Necessities Index and its indicators at each tehsil level and analysis of inequalities in access to bare necessities i.e., clean water, sanitation facilities,

\begin{tabular}{|c|c|c|c|c|c|c|c|c|c|c|c|c|c|c|c|c|}
\hline \multirow{3}{*}{$\begin{array}{l}\text { Sr. } \\
\text { No. }\end{array}$} & \multirow{3}{*}{$\begin{array}{l}\text { Tehsily } \\
\text { Sector }\end{array}$} & \multicolumn{9}{|c|}{ Water Sources } & \multicolumn{6}{|c|}{ Location of Source } \\
\hline & & \multicolumn{3}{|c|}{ Tap-Treated } & \multicolumn{3}{|c|}{ Tube/Borewell } & \multicolumn{3}{|c|}{ Well-Covered } & \multicolumn{3}{|c|}{ Within dwelling } & \multicolumn{3}{|c|}{ Outside dwelling } \\
\hline & & $T$ & R & $\mathrm{U}$ & $T$ & R & U & $T$ & $\mathrm{R}$ & $\mathrm{U}$ & $\mathbf{T}$ & $\mathbf{R}$ & U & $\mathrm{T}$ & R & U \\
\hline 1 & Shirala & 52.4 & 52.4 & $\cdot$ & 6.2 & 6.2 & - & 1.1 & 1.1 & $\cdot$ & 70.5 & 70.5 & . & 8.5 & 8.5 & . \\
\hline 2 & Walwa & 67.0 & 65.5 & 71.7 & 9.1 & 7.9 & 12.9 & 1.5 & 1.7 & 0.6 & 70.2 & 71.9 & 64.5 & 9.7 & 8.4 & 13.8 \\
\hline 3 & Palus & 72.0 & 72.0 & - & 6.3 & 6.3 & - & 0.5 & 0.5 & - & 76.7 & 76.7 & - & 5.1 & 5.1 & $\cdot$ \\
\hline 4 & Kadegaon & 46.3 & 46.3 & - & 12.3 & 12.3 & . & 2.7 & 2.7 & - & 57.8 & 57.8 & . & 13.1 & 13.1 & - \\
\hline 5 & Khanapur & 61.4 & 50.6 & 90.5 & 11.7 & 14.6 & 3.7 & 0.8 & 1.1 & 0.2 & 66.0 & 58.7 & 85.5 & 10.1 & 12.7 & 3.1 \\
\hline 6 & Atpadi & 31.8 & 31.8 & $\cdot$ & 3.2 & 3.2 & $\cdot$ & 1.6 & 1.6 & - & 49.8 & 49.8 & - & 17.5 & 17.5 & $\cdot$ \\
\hline 7 & Tasgaon & 60.2 & 57.0 & 78.8 & 16.9 & 18.7 & 6.4 & 0.7 & 0.7 & 0.6 & 66.5 & 64.4 & 78.9 & 9.2 & 10.1 & 3.7 \\
\hline 8 & Miraj & 75.9 & 55,0 & 88.4 & 8,4 & 15.7 & 4.0 & 0.5 & 1.2 & 0.2 & 74.6 & 63.2 & 81.5 & 7,1 & 11.2 & 4.7 \\
\hline 9 & K. Mahankal & 44.6 & 44.6 & - & 12.5 & 12.5 & - & 0.9 & 0.9 & $\cdot$ & 51.4 & 51.4 & - & 16.0 & 16.0 & - \\
\hline 10 & Jat & 19.1 & 19.1 & - & 13.2 & 13.2 & - & 2.2 & 2.2 & - & 34.2 & 34.2 & - & 26.4 & 26.4 & - \\
\hline \multicolumn{2}{|c|}{ Sangli District } & 59.0 & 49.5 & 85.7 & 9.9 & 11.5 & 5.4 & 1.1 & 1.4 & 0.2 & 64.8 & 59.7 & 79.2 & 11.3 & 13.2 & 5.8 \\
\hline
\end{tabular}
clean and safe cooking fuel, electricity access, and other bare necessities in Sangli district as follows-

Table -01

Tehsil \& Sector-wise Access of Water Sources with Location of Sangli District

Source: Census 2011/Sangil District (Note: T-Total, R-Rural, U-Urbani) 
Table -1 , shows the tehsils and sector-wise access of various water sources and location of water sources which is household has used in the Sangli district. Access to clean water is first main dimension of Bare Necessities Index. Observing the tehsils and sector-wise i.e., rural and urban use of main water sources, the main source of water is tap-treated water, mostly population of Palus total and urban has $72.0 \%$ individually, Khanapur urban has $90.5 \%$, it all higher as compared to ten tehsils. While, the use of the tap-treated source of water in overall Sangli district total, rural and urban have noted $59.0 \%, 49.5 \%$, and $85.7 \%$ respectively. The second one more important source of water is that tube/borewell, Tasgaon total, rural and urban has $16.9 \%, 18.7 \%$ and $6.4 \%$ of the population has using tube/borewell water source, which is higher as compared to eleven tehsils. While, with respect to overall Sangli district use of tube/borewell water source, there are $9.9 \%$ of the total, $11.5 \%$ of rural and $5.4 \%$ of the urban population have depending on tube/borewell water source. Use of well-covered water source, average $1.0 \%$ of the total, rural as well as urban population has using well-covered water source in all tehsils along with Sangli district.

Speaking about the location of water sources mentioned above, most of the population of all tehsils as well as a whole district have a water source within the dwelling as compared to the outside dwelling. Considering as whole Sangli district, there are $64.8 \%$ of the total, $59.7 \%$ of the rural and $79.2 \%$ of the urban population have water source is within the dwelling. On the other hand, water sources outside dwelling, whole Sangli district noted as $11.3 \%$ of the total, $13.2 \%$ of rural, and $5.8 \%$ of the urban populations have a water sources are outside or away from the dwelling.

Table - 02

Tehsil \& Sector-wise Access of Sanitation Facilities with Condition of Sangli District Values in \%

\begin{tabular}{|c|c|c|c|c|c|c|c|c|c|c|c|c|c|c|c|c|}
\hline \multirow{3}{*}{$\begin{array}{l}\text { Sr. } \\
\text { No. }\end{array}$} & \multirow{3}{*}{$\begin{array}{l}\text { Tehsil/ } \\
\text { Sector }\end{array}$} & \multirow{2}{*}{\multicolumn{3}{|c|}{ Access of Latrine }} & \multicolumn{12}{|c|}{ Latrine types } \\
\hline & & & & & \multicolumn{3}{|c|}{ Piped sewer system } & \multicolumn{3}{|c|}{ Septic tank } & \multicolumn{3}{|c|}{ Twin leach pit } & \multicolumn{3}{|c|}{ Single pit } \\
\hline & & $\mathrm{T}$ & $\mathrm{R}$ & $\mathrm{U}$ & $\mathrm{T}$ & $\mathrm{R}$ & $\mathrm{U}$ & $\mathrm{T}$ & $\mathrm{R}$ & $\mathrm{U}$ & $\mathrm{T}$ & $\mathrm{R}$ & $\mathrm{U}$ & $\mathrm{T}$ & $\mathrm{R}$ & $\mathrm{U}$ \\
\hline 1 & Shirala & 72.0 & 72.0 & - & 2.5 & 2.5 & - & 42.7 & 42.7 & $\cdot$ & 18.2 & 18.2 & $\cdot$ & 0.2 & 0.2 & $\cdot$ \\
\hline 2 & Walwa & 72.5 & 72.7 & 72.1 & 9.0 & 9.6 & 6.9 & 50.4 & 47.6 & 59.5 & 7.7 & 9.3 & 2.5 & 0.2 & 0.2 & 0.2 \\
\hline 3 & Palus & 76.3 & 76.3 & - & 9.5 & 9.5 & - & 58.4 & 58.4 & - & 6.3 & 6.3 & - & 0.1 & 0.1 & - \\
\hline 4 & Kadegaon & 74.5 & 74.5 & - & 2.3 & 2.3 & . & 26.0 & 26.0 & - & 42.9 & 42,9 & - & 0.3 & 0.3 & . \\
\hline 5 & Khanapu & 71.8 & 74.1 & 65.6 & 4.2 & 2.7 & 8.2 & 29.5 & 21.2 & 51.8 & 35.8 & 47.7 & 3.8 & 0.4 & 0.2 & 0.9 \\
\hline 6 & Atp & 51. & 51,4 & - & 1.4 & 1.4 & - & 18.8 & 18.8 & - & 29.3 & 29.3 & - & 0.1 & 0.1 & - \\
\hline 7 & Tasgaon & 60.7 & 60.4 & 62.3 & 2.2 & 2.2 & 2.3 & 33.7 & 29.7 & 57.2 & 23.2 & 26.9 & 1.5 & 0.1 & 0.1 & 0.2 \\
\hline 8 & Miraj & 71.1 & 55.1 & 80.7 & 20.3 & 3.8 & 30.1 & 41.4 & 41.1 & 41.6 & 5.6 & 8.5 & 3.9 & 0.3 & 0.2 & 0.4 \\
\hline 9 & K. Maha & 50.5 & 50.5 & - & 1.4 & 1.4 & - & 17.2 & 17.2 & · & 29.2 & 29.2 & - & 0.1 & 0.1 & - \\
\hline 10 & Jat & 34.8 & 34.8 & $\cdot$ & 1.0 & 1.0 & $\cdot$ & 10.5 & 10.5 & $\cdot$ & 21.4 & 21.4 & $\cdot$ & 0.6 & 0.6 & $\cdot$ \\
\hline \multicolumn{2}{|c|}{ Sangli District } & 64.9 & 60.5 & 77.6 & 9.2 & 4.0 & 24.0 & 35.8 & 32.4 & 45.5 & 16.3 & 20.8 & 3.6 & 0.3 & 0.2 & 0.4 \\
\hline
\end{tabular}

Source: Census 201//Sanghi District (Note: T-Total, R-Rural, U-Uiban)

Table -02, reveals that the tehsils and sector-wise access of sanitation facilities with structure i.e., latrine facility in Sangli district. A sanitation facility is a very basic necessity of each people should have. Sanitation is also known as the second important dimension of the Bare Necessities Index. Population access to latrine facility, Palus total and rural has $76.3 \%$ individually. While Jat total and rural has $34.8 \%$ individually. Use of latrine as whole Sangli district, $64.9 \%$ of the total, $60.5 \%$ of rural and $77.6 \%$ of the rural population has access to latrine facility. Observing that the structure or type of latrine facility that people have used, most of the people have used a septic tank and twin leach pit latrine as compared to piped sewer system and single pit latrine in all tehsils total, rural and urban areas as well as whole Sangli district. Use of Septic tank and twin leach pit latrine with respect to whole Sangli district, $35.8 \%$ of the total, $32.4 \%$ of rural, and $45.5 \%$ of urban people has using Septic tank latrine. While, $16.3 \%$ of the total, $20.8 \%$ of rural and $3.6 \%$ of the urban population have using twin leach pit latrine in Sangli district. 
Table -03

Tehsil \& Sector-wise Access of Housing Facilities with Condition of Sangli District （Values in \%)

\begin{tabular}{|c|c|c|c|c|c|c|c|c|c|c|}
\hline \multirow[t]{2}{*}{$\begin{array}{l}\text { Sr. } \\
\text { No. }\end{array}$} & \multirow{2}{*}{$\begin{array}{l}\text { Tehsil/ } \\
\text { Sector }\end{array}$} & \multicolumn{3}{|c|}{$\begin{array}{c}\text { Condition of Structure: } \\
\text { Good }\end{array}$} & \multicolumn{3}{|c|}{$\begin{array}{c}\text { Type of the dwelling: } \\
\text { Owned }\end{array}$} & \multicolumn{3}{|c|}{ Pucca dwelling } \\
\hline & & $\mathbf{T}$ & $\mathbf{R}$ & $\mathbf{U}$ & $\mathbf{T}$ & $\mathbf{R}$ & $\mathbf{U}$ & $\mathbf{T}$ & $\mathbf{R}$ & $\mathbf{U}$ \\
\hline 1 & Shirala & 71.0 & 71.0 & - & 93.3 & 93.3 & - & 98.9 & 98.9 & - \\
\hline 2 & Walwa & 70.9 & 70.3 & 73.1 & 87.5 & 90.4 & 77.8 & 95.8 & 95.7 & 96.8 \\
\hline 3 & Palus & 67.3 & 67.3 & - & 84.3 & 84.3 & - & 94.1 & 94.1 & - \\
\hline 4 & Kadegaon & 75.1 & 75.1 & - & 91.6 & 91.6 & - & 97.6 & 97.6 & - \\
\hline 5 & Khanapur & 70.3 & 70.4 & 70.1 & 84.6 & 90.6 & 68.7 & 94.4 & 93.5 & 97.2 \\
\hline 6 & Atpadi & 71.2 & 71.2 & - & 90.4 & 90.4 & - & 72.3 & 72.3 & - \\
\hline 7 & Tasgaon & 67.3 & 67.0 & 69.1 & 89.6 & 92.1 & 75.4 & 93.9 & 93.5 & 96.9 \\
\hline 8 & Miraj & 70.0 & 65.8 & 72.5 & 77.1 & 87.1 & 71.1 & 96.7 & 94.8 & 97.9 \\
\hline 9 & K. Mahankal & 65.1 & 65.1 & - & 90.9 & 90.9 & - & 84.5 & 84.5 & - \\
\hline 10 & Jat & 59.6 & 59.6 & - & 89.8 & 89.8 & - & 53.5 & 53.5 & - \\
\hline \multicolumn{2}{|c|}{ Sangli District } & 68.7 & 67.5 & 72.3 & 85.2 & 89.9 & 72.1 & 89.7 & 86.8 & 97.6 \\
\hline
\end{tabular}

Source: Census 2011/Sangli District (Note: T-Total, R-Rural, U-Urban)

Table -03 , shows that the tehsils and sector-wise access housing facilities with structure and types in respect to ten tehsils of Sangli district. A hosing facility with good conditions is an essential need to each people and it safeguards place for everyone and is also a third key dimension of the Bare Necessities Index. Talking about with respect to access to the good structure of housing facility, Kadegoan total and rural has $75.1 \%$ individually and Walwa urban has noted $73.1 \%$ it all higher as compare to ten tehsils. Access to a good condition of a housing facility in as whole Sangli district, noted at $68.7 \%$ of the total, $67.5 \%$ of rural and $72.3 \%$ of the urban population have a good structure of housing facility.

Tehsils and sector-wise observation of population access to Owned and 'Pucca' dwelling units, Shirala total and rural have counted $93.3 \%$ and 98.9 with respect to Owned and 'Pucca' dwelling units individually, Walwa urban and Miraj urban has $77.8 \%$ and $97.9 \%$ individually, which all higher as compared to ten tehsils. Considering as whole Sangli district access to an Owned dwelling, $85.2 \%$ of the total, $89.9 \%$ rural and $72.1 \%$ of urban people to have their Owned dwelling. While, about $89.7 \%$ of the total, $86.8 \%$ of the rural, and $97.6 \%$ of the urban population have 'Pucca' dwelling units in Sangli district.

Table - 04

Tehsil \& Sector-wise Access of Micro-Environment Facilities of Sangli District (Values in \%)

\begin{tabular}{clccccccccc}
\hline \multirow{2}{*}{$\begin{array}{c}\text { Sr. } \\
\text { No. }\end{array}$} & $\begin{array}{c}\text { Tehsil/ } \\
\text { Sector }\end{array}$ & \multicolumn{3}{c}{ No drainage } & \multicolumn{3}{c}{ Open drainage } & \multicolumn{3}{c}{ Use of Dirt Fuels for } \\
Cooking
\end{tabular}

Source: Census 2011/Sangli District (Note: T- Total, R-Rural, U-Urban)

Table -04, illustrates that tehsils and sector-wise access of Micro-environment facilities i.e., drainage facility, cooking fuel, etc. to the people in ten tehsils along with whole Sangli district. Micro-environment facilities are 
an important fragment of sanitation facilities, which is an essential and crucial part of each human life also it fourth important dimension of the Bare Necessities Index. There are all indicators of micro-environment all are negative. Speaking about the No-connectivity of drainage facility, Jat total and rural has $77.3 \%$ individually, both higher as compared ten tehsils. While Walwa total and urban has $33.6 \%$ and $26.4 \%$ respectively, Palus rural has $34.6 \%$ it all very lower as compared to ten tehsils. Observing No-connectivity of drainage facility as whole Sangli district total, rural and urban has $47.1 \%, 54.0 \%$, and $27.6 \%$ respectively.

About the situation of connectivity of Open-drainage, Shirala total and rural has noted nearly $54.0 \%$ individually, Tasgaon urban has $64.6 \%$ it all higher vis-versa Jat total and urban has $18.2 \%$ individually, Miraj urban is counted $37.0 \%$ which all lower as compared to ten tehsils. Use of dirt fuel i.e., firewood, kerosene, charcoal, etc., Shirala total and rural noted closely $77.0 \%$ individually, Walwa urban has $32.3 \%$ which all treated as higher. While Miraj total has $40.2 \%$, Palus rural has $43.4 \%$ and Tasgaon urban has $24.8 \%$ which all lower as compared to ten tehsils in Sangli district. Observing with respect to the connectivity of Open drainage and use of dirt fuel in the whole Sangli district there is 38.8\% of the total, 37.8\% of rural and $41.5 \%$ of urban population has using open drainage. While nearly $58.0 \%$ of the total, $68.5 \%$ of rural and $28.3 \%$ of the urban population have to depend on dirt fuel for cooking in the Sangli district.

Table -05

Tehsil \& Sector-wise Access of Other Facilities of Sangli District

\begin{tabular}{|c|c|c|c|c|c|c|c|c|c|c|c|c|c|c|c|c|}
\hline \multirow{3}{*}{$\begin{array}{l}\text { Sr. } \\
\text { No. }\end{array}$} & \multirow{3}{*}{ Tehsil/ Sector } & & \multirow{3}{*}{\multicolumn{3}{|c|}{$\begin{array}{l}\text { Use of modern fuel } \\
\text { for cooking: } L P G\end{array}$}} \\
\hline & & \multirow{2}{*}{\multicolumn{3}{|c|}{$\begin{array}{c}\text { Access of separate } \\
\text { kitchen }\end{array}$}} & \multicolumn{6}{|c|}{ Bathing Facility } & \multirow{2}{*}{\multicolumn{3}{|c|}{$\begin{array}{l}\text { Access of } \\
\text { electricity }\end{array}$}} & & & \\
\hline & & & & & \multicolumn{3}{|c|}{ No bathroom } & \multicolumn{3}{|c|}{ Access of Bathroom } & $T$ & & & & & \\
\hline 1 & & 826 & 826 & & 64 & 64 & & 935 & 935 & $=$ & 911 & 911 & 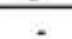 & 13.8 & 138 & - \\
\hline 2 & Walwa & 84.3 & 83.2 & 88.1 & 8.8 & 9.6 & 6.2 & 91.2 & 90.4 & 93.8 & 91.5 & 913 & 92.2 & 40.0 & 32.2 & 65.4 \\
\hline 3 & Palus & 83.5 & 83.5 & - & 8.6 & 8.6 & - & 91.5 & 91.5 & - & 90.9 & 90.9 & - & 53.0 & 53.0 & - \\
\hline 4 & Kadegaon & 76.3 & 76.3 & - & 7.8 & 7.8 & - & 92.2 & 92.2 & - & 86.6 & 86.6 & - & 25.4 & 25.4 & - \\
\hline 5 & Khanapur & 74.8 & 73.2 & 79.2 & 8.8 & 9.7 & 6.3 & 91.1 & 90.3 & 93.6 & 86.6 & 83.6 & 94.7 & 41.1 & 31.4 & 67.1 \\
\hline 6 & Atpadi & 54.5 & 54.5 & - & 21.8 & 21.8 & - & 78.2 & 78.2 & - & 74.6 & 74.6 & - & 14.8 & 14.8 & - \\
\hline 7 & Tasgaon & 78.1 & 77.7 & 80.3 & 12.4 & 12.6 & 11.4 & 87.6 & 87.4 & 88.6 & 82.6 & 80.7 & 93.9 & 40,0 & 34.3 & 73.8 \\
\hline 8 & Miraj & 81.7 & 79.6 & 82.9 & 8.2 & 14.8 & 4.3 & 91.8 & 85.2 & 95.6 & 91.1 & 82.9 & 96.1 & 58.3 & 37.0 & 71.0 \\
\hline 9 & K. Mahankal & 71.3 & 71.3 & - & 18.3 & 18.3 & - & 81.7 & 81.7 & - & 71.9 & 71.9 & - & 23.0 & 23.0 & - \\
\hline 10 & Jat & 60.7 & 60.7 & - & 24.5 & 24.5 & - & 75.5 & 75.5 & $\cdot$ & 43.9 & 43.9 & $\cdot$ & 10.7 & 10.7 & $\cdot$ \\
\hline & angli District & 77.1 & 74.9 & 83.3 & 11.6 & 13.9 & 51 & 88.4 & 86.1 & 95.0 & 82.9 & 78.5 & 95.3 & 38.8 & 27.7 & 70.1 \\
\hline
\end{tabular}

Source: Censwis 201 LSangh District Aote: T-Total, R-Rural, U-Uiban)

Table -05 , shows that tehsils and sector-wise access of Other facilities i.e., bathing facility, clean and modern cooking fuel, access of electricity, separate kitchen, etc. to the people in ten tehsils along with whole Sangli district. Other facilities noted above which is played an important role in individual hygiene and human health, also it fifth vital dimension of the Bare Necessities Index. The five indicators of the Other facilities dimension have been finalized and it divided into three positive and two negatives. Speaking about tehsils and sector-wise access of separate kitchen, Walwa total and urban has nearly $84.3 \%$ and $88.1 \%$, Palus rural has $83.5 \%$ which all higher as compared ten tehsils. While Atpadi total and rural has 54.5\% individually, Khanapur urban notes at $79.2 \%$ it all treated lower as compared to ten tehsils. Considering as whole Sangli district total, rural and urban has $77.1 \%, 79.4 \%$, and $83.3 \%$ respectively.

Observing the access to the bathing facility, most of the tehsil's total, rural and urban population i.e., Shirala, Walwa Palus, Kadegoan, Khanapur, etc., noted above $90.0 \%$ of the population have access to bathroom facility. While Jat total and rural has reported nearly 75.5.0\% individually, which all lower as compared to ten tehsils. About lack or No-bathing facility, Atpadi, Tasgaon and K. Mahankal total, rural along with urban areas most of the population has lack of bathing facility as compared to ten tehsils. The access of electricity, in Sangli district, there is $82.9 \%$ of the total, $78.5 \%$ of rural and $95.3 \%$ of the urban population has access to electricity. While, use of modern and clean cooking fuel i.e., LPG, in the whole Sangli district nearly $38.8 \%$ of the total, $27.7 \%$ of the rural and $70.1 \%$ of the urban population have used modern and clean fuel for cooking. 


\section{International Journal of Southern Economic Light (JSEL)}

- Peer Review Journal

Table -06

Tehsil \& Secter-wise Water Index \& its Indices of Sangli District

\begin{tabular}{|c|c|c|c|c|c|c|c|c|c|c|c|c|c|c|c|c|c|c|c|}
\hline \multirow{3}{*}{$\begin{array}{l}\text { Sr. } \\
\text { Na. }\end{array}$} & \multirow{3}{*}{$\begin{array}{l}\text { Tehsill } \\
\text { Sector }\end{array}$} & \multicolumn{9}{|c|}{ Water Sources } & \multicolumn{6}{|c|}{ Location of Source } & \multirow{2}{*}{\multicolumn{3}{|c|}{$\begin{array}{c}\text { Water Index } \\
\text { (WI) }\end{array}$}} \\
\hline & & \multicolumn{3}{|c|}{ Tap-Treated } & \multicolumn{3}{|c|}{ Tube/Borewell } & \multicolumn{3}{|c|}{ Well-Cosered } & \multicolumn{3}{|c|}{ Within dwelling } & \multicolumn{3}{|c|}{ Outside dwelling } & & & \\
\hline & & $\mathrm{T}$ & $\mathbf{R}$ & U & $T$ & $\mathrm{R}$ & $\mathrm{U}$ & $\mathrm{T}$ & $\mathbf{R}$ & U & $\mathbf{T}$ & $\mathbf{R}$ & U & $T$ & $\mathrm{R}$ & U & $\mathrm{T}$ & $\mathbf{R}$ & $\mathrm{U}$ \\
\hline 1 & Shirala & 0.52 & 0.52 & . & 0.06 & 0.06 & - & 0.01 & 0.01 & - & 0.71 & 0.71 & - & 0.09 & 0.09 & - & 0.28 & 0.28 & - \\
\hline 2 & Walwa & 0.67 & 0.66 & 0.72 & 0.09 & 0.08 & 0.13 & 0.02 & 0.02 & 0.01 & 0.70 & 0.72 & 0.65 & 0.10 & 0.08 & 0.14 & 0.32 & 0.31 & 0.33 \\
\hline 3 & Palus & 0.72 & 0.72 & - & 0.06 & 0.06 & $\cdot$ & 0.01 & 0.01 & - & 0.77 & 0.77 & - & 0.05 & 0.05 & $\cdot$ & 0.32 & 0.32 & - \\
\hline 4 & Kadegaon & 0.46 & 0.46 & - & 0.12 & 0.12 & - & 0.03 & 0.03 & . & 0.58 & 0.58 & - & 0.13 & 0.13 & - & 0.26 & 0.26 & - \\
\hline 5 & Khanapur & 0.61 & 0.51 & 0.91 & 0.12 & 0.15 & 0.04 & 0.01 & 0.01 & 0.00 & 0.66 & 0.59 & 0.86 & 0.10 & 0,13 & 0.03 & 0.30 & 0.28 & 0.37 \\
\hline 6 & Atpadi & 0.32 & 0.32 & - & 0.03 & 0.03 & $\cdot$ & 0.02 & 0.02 & - & 0.50 & 0.50 & - & 0,18 & 0.18 & - & 0.21 & 0.21 & - \\
\hline 7 & Tasgaon & 0.60 & 0.57 & 0.79 & 0.17 & 0.19 & 0.06 & 0.01 & 0.01 & 0.01 & 0.67 & 0.64 & 0.79 & 0.09 & 0.10 & 0.04 & 0.31 & 0.30 & 0.34 \\
\hline 8 & Miraj & 0.76 & 0.55 & 0.88 & 0.08 & 0.16 & 0.04 & 0.01 & 0.01 & 0.00 & 0.75 & 0.63 & 0.82 & 0.07 & 0.11 & 0,05 & 0.33 & 0.29 & 0.36 \\
\hline 9 & K. Mahankal & 0.45 & 0.45 & - & 0,13 & 0.13 & - & 0.01 & 0.01 & - & 0.51 & 0.51 & - & 0.16 & 0,16 & $\cdot$ & 0.25 & 0.25 & - \\
\hline 10 & Jat & 0.19 & 0.19 & . & 0.13 & 0.13 & - & 0.02 & 0.02 & - & 0.34 & 0.34 & - & 0.26 & 0.26 & - & 0.19 & 0.19 & - \\
\hline \multicolumn{2}{|c|}{ Sangli District } & 0.59 & 0.50 & 0.86 & 0.10 & 0.12 & 0.05 & 0.01 & 0.01 & 0.00 & 0.65 & 0.60 & 0.79 & 0.11 & 0.13 & 0.06 & 0.29 & 0.29 & 0.27 \\
\hline
\end{tabular}

Figure - 01

0.400

0.300

0.200

0.100

0.000

Tehsils \& Sector-wise Water Index (WI) of Sangli District

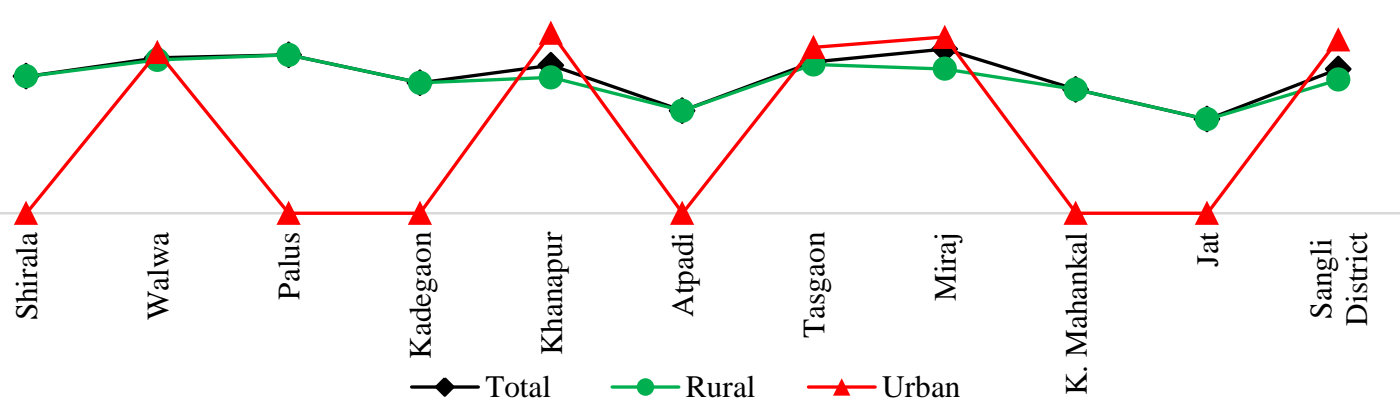

Table -06 \& Fig. 01 indicates the tehsil and sector-wise Water Index and its sub-indicators indices of the Sangli district across ten tehsils. There is the high-water index indicates high access to water sources, the medium index is medium, and the very low index is very low access to water sources to the people respectively. Observing the Water Index of the Miraj total has 0.33, Palus rural has 0.32 and Khanapur urban has 0.37 it all higher as compared to ten tehsils, and which all comes under very low category. While Jat total and rural has noted 0.19 individually, Walwa urban has 0.33 which all lower and exited under very low category. Considering the improvement in the Water Index of the whole Sangli district total, rural and urban noted nearly $0.29,0.29$, and 0.27 respectively which all existed under very low category. The sectorial Water Index of the whole Sangli district reveals that the access of water sources to total as well as rural people is better than urban people. Shortly, on the basis of overall estimation of the Water Index of the whole Sangli district illustrates that most of the population has to struggle to get clean water in total, rural as well as urban areas in Sangli district. 


\section{International Journal of Southern Economic Light (JSEL)}

- Peer Review Journal

Table -67

Tehsil \& Sector-wise Sanitation Index \& its Indices of Sangli District

\begin{tabular}{|c|c|c|c|c|c|c|c|c|c|c|c|c|c|c|c|c|c|c|c|}
\hline \multirow{3}{*}{$\begin{array}{l}\text { Sr. } \\
\text { No. }\end{array}$} & \multirow{3}{*}{$\begin{array}{l}\text { Tehsil/ } \\
\text { Sector }\end{array}$} & \multirow{2}{*}{\multicolumn{3}{|c|}{ Access of Latrine }} & \multicolumn{12}{|c|}{ Latrine types } & \multirow{2}{*}{\multicolumn{3}{|c|}{$\begin{array}{l}\text { Sanitation Index } \\
\text { (SI) }\end{array}$}} \\
\hline & & & & & \multicolumn{3}{|c|}{$\begin{array}{l}\text { Piped sewer } \\
\text { system }\end{array}$} & \multicolumn{3}{|c|}{ Septic tank } & \multicolumn{3}{|c|}{ Twin leach pit } & \multicolumn{3}{|c|}{ Single pit } & & & \\
\hline & & $\mathrm{T}$ & $\mathrm{R}$ & U & $\mathrm{T}$ & $\mathrm{R}$ & $\mathrm{U}$ & $\mathrm{T}$ & $\mathrm{R}$ & $\mathrm{U}$ & $\mathrm{T}$ & $\mathrm{R}$ & U & $\mathrm{T}$ & $\mathbf{R}$ & U & $\mathrm{T}$ & $\mathrm{R}$ & U \\
\hline 1 & Shirala & 0.72 & 0.72 & - & 0.03 & 0.03 & - & 0.43 & 0.43 & . & 0.18 & 0.18 & . & 0.00 & 0.00 & . & 0.27 & 0.27 & - \\
\hline 2 & Walwa & 0.73 & 0.73 & 0.72 & 0.09 & 0.10 & 0.07 & 0.50 & 0.48 & 0.60 & 0.08 & 0.09 & 0.03 & 0.00 & 0.00 & 0.00 & 0.28 & 0.28 & 0.28 \\
\hline 3 & Palus & 0.76 & 0.76 & $\cdot$ & 0.10 & 0.10 & $\cdot$ & 0.58 & 0.58 & - & 0.06 & 0.06 & - & 0.00 & 0.00 & - & 0.30 & 0.30 & - \\
\hline 4 & Kadegaon & 0.75 & 0.75 & - & 0.02 & 0.02 & - & 0.26 & 0.26 & - & 0.43 & 0,43 & - & 0.00 & 0.00 & - & 0.29 & 0.29 & - \\
\hline 5 & Khanapur & 0.72 & 0.74 & 0.66 & 0.04 & 0.03 & 0.08 & 0.30 & 0.21 & 0.52 & 0.36 & 0,48 & 0.04 & 0.00 & 0.00 & 0.01 & 0.28 & 0.29 & 0.26 \\
\hline 6 & Alpadi & 0.51 & 0.51 & - & 0.01 & 0.01 & - & 0.19 & 0.19 & - & 0.29 & 0.29 & - & 0,00 & 0.00 & - & 0.20 & 0.20 & - \\
\hline 7 & Tasgaon & 0.61 & 0,60 & 0.62 & 0,02 & 0.02 & 0.02 & 0.34 & 0.30 & 0.57 & 0.23 & 0.27 & 0.02 & 0.00 & 0.00 & 0.00 & 0.24 & 0.24 & 0.25 \\
\hline 8 & Miraj & 0.71 & 0.55 & 0.81 & 0.20 & 0.04 & 0.30 & 0.41 & 0.41 & 0.42 & 0.06 & 0.09 & 0.04 & 0.00 & 0.00 & 0.00 & 0.28 & 0.22 & 0.31 \\
\hline 9 & $\begin{array}{l}\text { K. } \\
\text { Mahankal }\end{array}$ & 0.51 & 0.51 & - & 0.01 & 0.01 & - & 0.17 & 0.17 & - & 0.29 & 0.29 & - & 0.00 & 0.00 & - & 0.20 & 0.20 & - \\
\hline 10 & Jat & 0.35 & 0.35 & - & 0.01 & 0.01 & - & 0.11 & 0.11 & - & 0.21 & 0.21 & - & 0.01 & 0,01 & - & 0.14 & 0.14 & - \\
\hline Sa & gli District & 0.65 & 0.61 & 0.78 & 0.09 & 0.04 & 0.24 & 0.36 & 0.32 & 0.46 & 0.16 & 0.21 & 0.04 & 0.00 & 0.00 & 0.00 & 0.25 & 0.24 & 0.30 \\
\hline
\end{tabular}

Sowce: Authors Calctilation frome table-02 (Note: T-TotaL, R-Rial, U-Urban)

Figure - 02

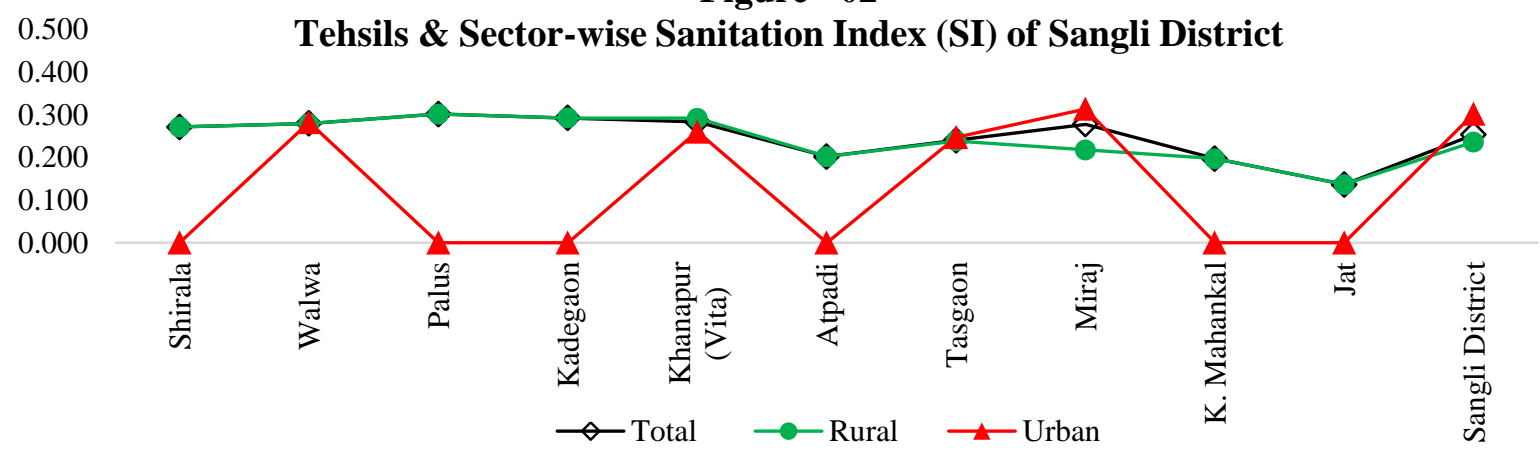

Table $-07 \&$ Fig. 02 shows that the tehsil and sector-wise Sanitation Index and its sub-indicator indices of Sangli district. Sanitation Index has grouped into three categories, which indicates that the high-sanitation index is high access to sanitation facilities, the medium index is medium, and the very low index is very low access to sanitation facilities to the people respectively. Looking at the tehsil-wise and sectorial Sanitation Index, Palus total and rural has noted 0.30 individually, Miraj urban has 0.31 , it all higher but it comes under the very low category as compared to ten tehsils of Sangli district.

While Jat total and rural has calculated 0.14 individually, Tasgaon urban has 0.25 it all very lower and in addition to the very low category. Seeing the overall estimation of Sanitation Index as whole Sangli district with respect sectoral i.e., total, rural, and urban has $0.25,0.24$, and 0.30 singly, which all comes under very low category. Briefly, the overall Sanitation Index of the whole Sangli district reveals that the access of sanitation facilities to people in total, rural as well as urban areas has very low, but the access of sanitation facilities to urban people is better than total as well as rural people in Sangli district. 
Table -08

Tehsil \& Sector-wise Housing Index \& its Indices of Sangli District

\begin{tabular}{|c|c|c|c|c|c|c|c|c|c|c|c|c|c|}
\hline \multirow{2}{*}{$\begin{array}{l}\text { Sr. } \\
\text { No. }\end{array}$} & \multirow{2}{*}{$\begin{array}{l}\text { Tehsil/ } \\
\text { Sector }\end{array}$} & \multicolumn{3}{|c|}{$\begin{array}{c}\text { Condition of } \\
\text { Structure: Good }\end{array}$} & \multicolumn{3}{|c|}{$\begin{array}{c}\text { Type of the } \\
\text { dwelling: Owned }\end{array}$} & \multicolumn{3}{|c|}{ Pucca dwelling } & \multicolumn{3}{|c|}{$\begin{array}{c}\text { Housing Index } \\
\text { (HI) }\end{array}$} \\
\hline & & $\mathbf{T}$ & $\mathbf{R}$ & $\mathbf{U}$ & $\mathbf{T}$ & $\mathbf{R}$ & $\mathbf{U}$ & $\mathbf{T}$ & $\mathbf{R}$ & $\mathbf{U}$ & $\mathbf{T}$ & $\mathbf{R}$ & $\mathbf{U}$ \\
\hline 1 & Shirala & 0.71 & 0.71 & - & 0.93 & 0.93 & - & 0.99 & 0.99 & - & 0.88 & 0.88 & - \\
\hline 2 & Walwa & 0.71 & 0.70 & 0.73 & 0.88 & 0.90 & 0.78 & 0.96 & 0.96 & 0.97 & 0.85 & 0.85 & 0.83 \\
\hline 3 & Palus & 0.67 & 0.67 & - & 0.84 & 0.84 & - & 0.94 & 0.94 & - & 0.82 & 0.82 & - \\
\hline 4 & Kadegaon & 0.75 & 0.75 & - & 0.92 & 0.92 & - & 0.98 & 0.98 & - & 0.88 & 0.88 & - \\
\hline 5 & Khanapur & 0.70 & 0.70 & 0.70 & 0.85 & 0.91 & 0.69 & 0.94 & 0.94 & 0.97 & 0.83 & 0.85 & 0.79 \\
\hline 6 & Atpadi & 0.71 & 0.71 & - & 0.90 & 0.90 & - & 0.72 & 0.72 & - & 0.78 & 0.78 & - \\
\hline 7 & Tasgaon & 0.67 & 0.67 & 0.69 & 0.90 & 0.92 & 0.75 & 0.94 & 0.94 & 0.97 & 0.84 & 0.84 & 0.80 \\
\hline 8 & Miraj & 0.70 & 0.66 & 0.73 & 0.77 & 0.87 & 0.71 & 0.97 & 0.95 & 0.98 & 0.81 & 0.83 & 0.81 \\
\hline 9 & K. Mahankal & 0.65 & 0.65 & - & 0.91 & 0.91 & - & 0.85 & 0.85 & - & 0.80 & 0.80 & - \\
\hline 10 & Jat & 0.60 & 0.60 & - & 0.90 & 0.90 & - & 0.54 & 0.54 & - & 0.68 & 0.68 & - \\
\hline \multicolumn{2}{|c|}{ Sangli District } & 0.69 & 0.68 & 0.72 & 0.85 & 0.90 & 0.72 & 0.90 & 0.87 & 0.98 & 0.81 & 0.81 & 0.81 \\
\hline
\end{tabular}

Source: Authors Calculation/ from table-03 (Note: T-Total, R-Rural, U-Urban)

Figure - 03

1.000
0.800
0.600
0.400
0.200
0.000

Tehsils \& Sector-wise Housing Index (HI) of Sangli District

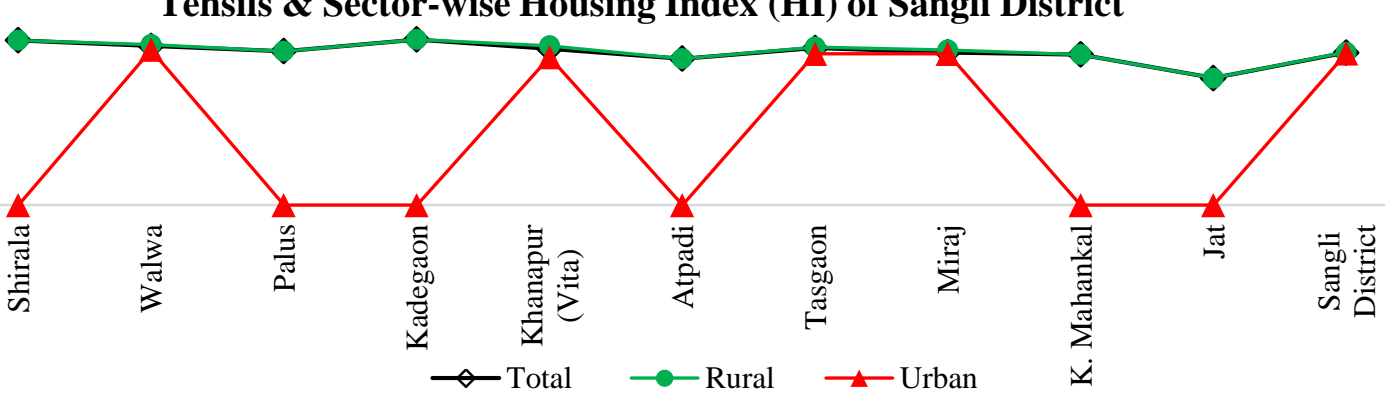

Table $-08 \&$ Fig. 03 shows that the tehsil and sector-wise Housing Index and its sub-indicator indices of Sangli district across ten tehsils. Housing Index has categorized into three categories, which indicates that the highhousing index is high access to satisfactory and well condition housing facilities, the medium index is medium, and the very low index is very low respectively. About the tehsil and sector-wise Housing Index, Shirala and Kadegoan total and rural have been noted 0.88 and 0.88 individually, Walwa urban has 0.83 , it all shows higher and also comes under the high category as compared to ten tehsils. On the Other hand, only Jat total and rural has counted 0.68 individually, Khanapur urban has 0.79 which all lower and except Jat total and rural, Khanapur urban existed under medium category. Considering at overall Housing Index of the whole Sangli district with respect to sectoral i.e., total, rural, and urban has been counted 0.81 singly, which all comes under the high category. Shortly, the Housing Index of Sangli district indicating that the access of well-constructed housing facilities to total, rural as well as urban people is better in all tehsils along with as whole Sangli district. 
Table -09

Tehsil \& Sector-wise Micro-Environment Index \& its Indices of Sangli District $\quad$ (Values in \%)

\begin{tabular}{|c|c|c|c|c|c|c|c|c|c|c|c|c|c|}
\hline \multirow{2}{*}{$\begin{array}{l}\text { Sr. } \\
\text { No. }\end{array}$} & \multirow{2}{*}{$\begin{array}{l}\text { Tehsil/ } \\
\text { Sector }\end{array}$} & \multicolumn{3}{|c|}{ No drainage } & \multicolumn{3}{|c|}{ Open drainage } & \multicolumn{3}{|c|}{$\begin{array}{l}\text { Use of Dirt Fuel } \\
\text { for Cooking }\end{array}$} & \multicolumn{3}{|c|}{$\begin{array}{l}\text { Micro-Environment } \\
\text { Index (MEI) }\end{array}$} \\
\hline & & $\mathbf{T}$ & $\mathbf{R}$ & $\mathbf{U}$ & $\mathbf{T}$ & $\mathbf{R}$ & $\mathbf{U}$ & $\mathbf{T}$ & $\mathbf{R}$ & $\mathbf{U}$ & $\mathbf{T}$ & $\mathbf{R}$ & $\mathbf{U}$ \\
\hline 1 & Shirala & 0.39 & 0.39 & - & 0.54 & 0.54 & - & 0.77 & 0.77 & - & 0.57 & 0.57 & - \\
\hline 2 & Walwa & 0.34 & 0.36 & 0.26 & 0.52 & 0.50 & 0.57 & 0.52 & 0.58 & 0.32 & 0.46 & 0.48 & 0.38 \\
\hline 3 & Palus & 0.35 & 0.35 & - & 0.52 & 0.52 & - & 0.43 & 0.43 & - & 0.43 & 0.43 & - \\
\hline 4 & Kadegaon & 0.54 & 0.54 & - & 0.37 & 0.37 & - & 0.72 & 0.72 & - & 0.54 & 0.54 & - \\
\hline 5 & Khanapur & 0.52 & 0.55 & 0.43 & 0.37 & 0.34 & 0.45 & 0.57 & 0.67 & 0.31 & 0.49 & 0.52 & 0.39 \\
\hline 6 & Atpadi & 0.75 & 0.75 & - & 0.19 & 0.19 & - & 0.84 & 0.84 & - & 0.59 & 0.59 & - \\
\hline 7 & Tasgaon & 0.53 & 0.58 & 0.28 & 0.41 & 0.37 & 0.62 & 0.58 & 0.64 & 0.25 & 0.51 & $\mathbf{0 . 5 3}$ & 0.38 \\
\hline 8 & Miraj & 0.35 & 0.49 & 0.27 & 0.39 & 0.44 & 0.37 & 0.40 & 0.61 & 0.27 & 0.38 & 0.51 & 0.30 \\
\hline 10 & K. Mahankal & 0.70 & 0.70 & - & 0.25 & 0.25 & - & 0.74 & 0.74 & - & 0.57 & 0.57 & - \\
\hline 11 & Jat & 0.77 & 0.77 & - & 0.18 & 0.18 & - & 0.89 & 0.89 & - & 0.61 & 0.61 & - \\
\hline \multicolumn{2}{|c|}{ Sangli District } & 0.47 & 0.54 & 0.28 & 0.39 & 0.38 & 0.42 & 0.58 & 0.69 & 0.28 & 0.48 & $\mathbf{0 . 5 3}$ & 0.32 \\
\hline
\end{tabular}

Source: Authors Calculation/from table-04 (Note: T-Total, R-Rural, U-Urban)

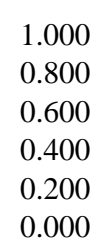

Figure - 04

1.000
0.600
0.400
0.200
0.000

Tehsils \& Sector-wise Micro-Environment Index (MEI) of Sangli District

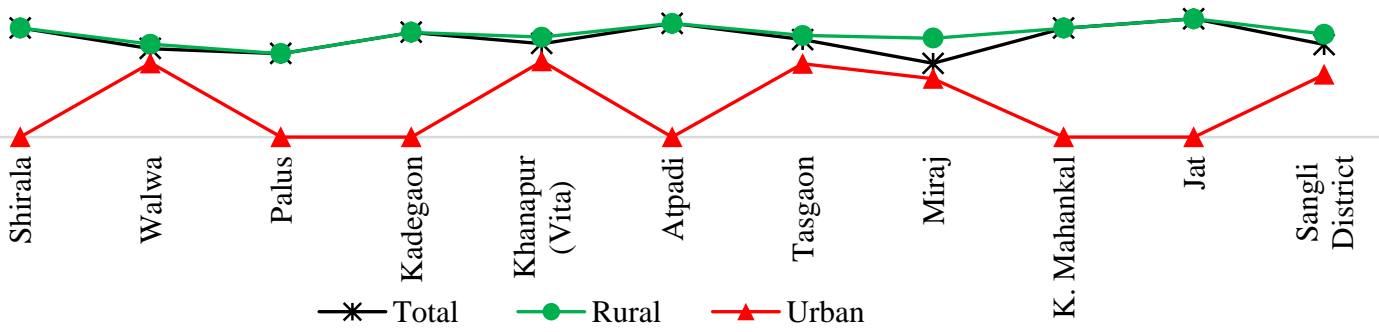

Table - 09 \& Fig. 04 indicates that the tehsil and sector-wise Micro-Environment Index and its sub-indicator indices of Sangli district across ten tehsils. Micro-Environment Index has categorized into three categories, which indicates that the high-micro-environment index is high access to micro-environmental facilities i.e., drainage, cooking fuel, etc., the medium index is medium, and the very low index is very low respectively. Tehsil and sector-wise Micro-Environment Index of Jat total and rural have been calculated 0.61 singly, Walwa urban has 0.38 , which all higher and except Jat total and rural Walwa urban comes under the very low category as compared to ten tehsils. While Miraj total and rural has been nearly recorded 0.38 and 0.30 respectively, Palus and Walwa urban has closely 0.43 and 0.48 individually, it all lower and existed under very low category. Looking at the overall Micro-Environment Index of the whole Sangli district along with sectoral i.e., total, rural, and urban has noted $0.48,0.53$, and 0.32 respectively, which except rural all comes under very low category. Briefly, according to the estimated Micro-Environment Index of Sangli district is showing that the access of microenvironment facilities i.e., drainage connectivity, cooking fuel, etc., to total, rural as well as urban people is inadequate in all tehsils along with Sangli district. 


\section{International Journal of Southern Economic Light (JSEL)}

- Peer Review Journal

\section{Table - 10}

Tehsil \& Sector-wise Other Facilities Index \& its Indices of Sangli District

\begin{tabular}{|c|c|c|c|c|c|c|c|c|c|c|c|c|c|c|c|c|c|c|c|}
\hline \multirow{3}{*}{$\begin{array}{l}\text { Sr. } \\
\text { No. }\end{array}$} & \multirow{3}{*}{$\begin{array}{l}\text { Tehsil/ } \\
\text { Sector }\end{array}$} & \multirow{2}{*}{\multicolumn{3}{|c|}{$\begin{array}{c}\text { Access of separate } \\
\text { kitchen }\end{array}$}} & \multicolumn{6}{|c|}{ Bathing Pacility } & \multirow{2}{*}{\multicolumn{3}{|c|}{$\begin{array}{l}\text { Access of } \\
\text { electricity }\end{array}$}} & \multirow{2}{*}{\multicolumn{3}{|c|}{$\begin{array}{c}\text { Use of modern } \\
\text { fuel for cooking: } \\
\text { LPG }\end{array}$}} & \multirow{2}{*}{\multicolumn{3}{|c|}{$\begin{array}{c}\text { Other Facilities } \\
\text { Index (OF) }\end{array}$}} \\
\hline & & & & & \multicolumn{3}{|c|}{ No bathroom } & \multicolumn{3}{|c|}{$\begin{array}{l}\text { Access of } \\
\text { Bathroom }\end{array}$} & & & & & & & & & \\
\hline & & $\mathrm{T}$ & $\mathbf{R}$ & $\mathbf{U}$ & $\mathrm{T}$ & $\mathrm{R}$ & $\mathbf{U}$ & $\mathbf{T}$ & $\mathrm{R}$ & $\mathrm{U}$ & $\mathbf{T}$ & $\mathrm{R}$ & U & $T$ & $\mathbf{R}$ & $\mathrm{U}$ & $\mathrm{T}$ & $\mathbf{R}$ & U \\
\hline 1 & Shirala & 0.83 & 0.83 & - & 0.06 & 0.06 & - & 0.94 & 0.94 & - & 0.91 & 0.91 & - & 0.14 & 0.14 & - & 0.57 & 0.57 & - \\
\hline 2 & Walwa & 0.84 & 0.83 & 0.88 & 0.09 & 0.10 & 0.06 & 0.91 & 0.90 & 0.94 & 0.92 & 0.91 & 0.92 & 0.40 & 0.32 & 0.65 & 0.63 & 0.61 & 0.69 \\
\hline 3 & Palus & 0.84 & 0.84 & - & 0.09 & 0,09 & - & 0.92 & 0.92 & - & 0.91 & 0,91 & - & 0.53 & 0.53 & - & 0.66 & 0.66 & - \\
\hline 4 & Kadegaon & 0.76 & 0.76 & $\cdot$ & 0.08 & 0.08 & $\cdot$ & 0.92 & 0.92 & $\cdot$ & 0.87 & 0.87 & - & 0.25 & 0.25 & - & 0.58 & 0.58 & - \\
\hline 5 & Khanapur & 0.75 & 0.73 & 0.79 & 0.09 & 0.10 & 0.06 & 0.91 & 0.90 & 0.94 & 0.87 & 0.84 & 0.95 & 0.41 & 0.31 & 0.67 & 0.60 & 0.58 & 0.68 \\
\hline 6 & Atpadi & 0.55 & 0.55 & . & 0.22 & 0.22 & - & 0.78 & 0.78 & - & 0.75 & 0.75 & - & 0.15 & 0.15 & - & 0.49 & 0.49 & - \\
\hline 7 & 'Tasgaon & 0.78 & 0.78 & 0.80 & 0.12 & 0.13 & 0.11 & 0.88 & 0.87 & 0.89 & 0.83 & 0.81 & 0.94 & 0.40 & 0.34 & 0.74 & 0.60 & 0.59 & 0.70 \\
\hline 8 & Miraj & 0.82 & 0.80 & 0.83 & 0,08 & 0.15 & 0.04 & 0.92 & 0.85 & 0.96 & 0.91 & 0.83 & 0.96 & 0.58 & 0.37 & 0.71 & 0.66 & (0.60) & 0.70 \\
\hline 9 & $\begin{array}{l}\text { K. } \\
\text { Mahankal }\end{array}$ & 0.71 & 0.71 & - & 0.18 & 0.18 & - & 0.82 & 0.82 & . & 0.72 & 0.72 & - & 0.23 & 0.23 & - & 0.53 & 0.53 & - \\
\hline 10 & Jat & 0.61 & 0.61 & - & 0.25 & 0.25 & - & 0,76 & 0.76 & - & 0.44 & 0.44 & - & 0.11 & 0.11 & - & 0.43 & 0.43 & - \\
\hline \multicolumn{2}{|c|}{ Sangli District } & 0.77 & 0.75 & 0.83 & 0.12 & 0.14 & 0.05 & 0.88 & 0.86 & 0.95 & 0.83 & 0.79 & 0.95 & 0.39 & 0.28 & 0.70 & 0.60 & 0.56 & 0.70 \\
\hline
\end{tabular}

Source: Authors Calculation from toble-05 (Note: T- Total, R-Rural, U-Unban)

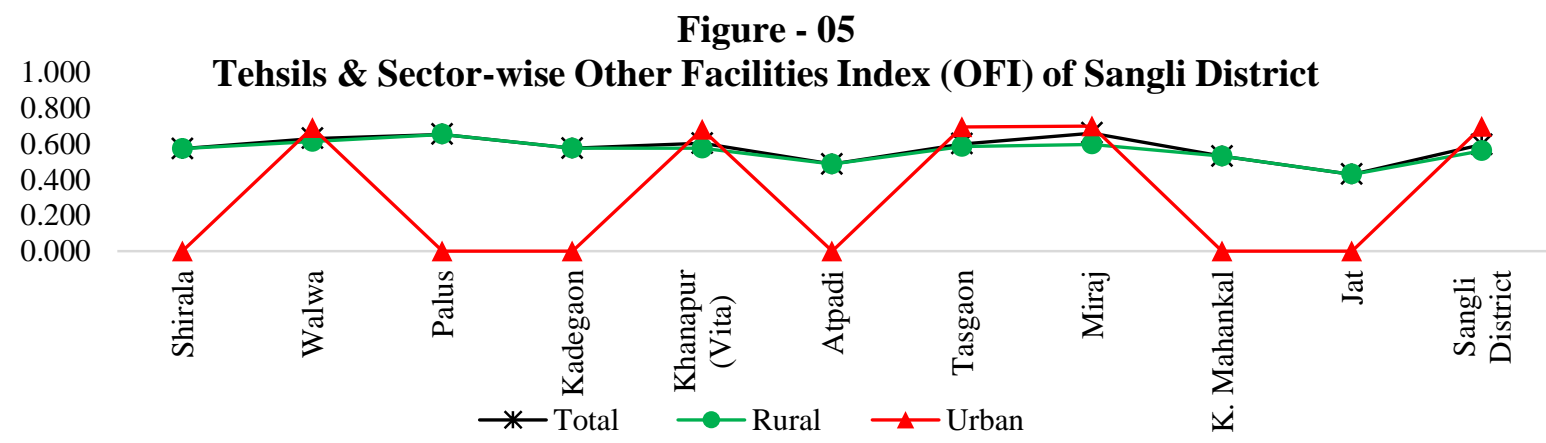

Table - 10 \& Fig. 05 illustrates that the tehsil and sector-wise Other Facilities Index and its sub-indicator indices of Sangli district across ten tehsils. Other Facilities Index has grouped into three categories, which reveals that the high Other Facilities Index is high, the medium index is medium, and the very low index is very low access to other facilities i.e., bathing, clean cooking fuel, separate kitchen, access to electricity, etc., respectively. Tehsil and sector-wise Other Facilities Index of Palus total and rural have been calculated 0.66 singly as well as Miraj total and urban has 0.66 and 0.70 individually which all higher but except Miraj urban it all comes under the medium category as compared to ten tehsils. While Jat total and rural has been recorded nearly 0.43 respectively, Khanapur urban has 0.68 , which all lower and except Khanapur urban other all existed under very low category.

Considering as overall Other Facilities Index of the whole Sangli district along with sector i.e., total, rural, and urban has been calculated at $0.60,0.56$, and 0.70 singly, which is except urban all stood under medium category. Briefly, as per estimated Other Facilities Index of Sangli district is showing that the access of other facilities i.e., bathing, clean cooking fuel, separate kitchen, access to electricity, etc., to urban people is better than total and rural in Sangli district. 


\title{
International Journal of Southern Economic Light (JSEL)
}

- Peer Review Journal

\author{
Table - 11
}

Tehsil \& Sector -wise Bear Necessities Index (BNI) of Sangli District (Total/Rural/Urban)

\begin{tabular}{|c|c|c|c|c|c|c|c|}
\hline Sr. No. & Tehsil & Total & Rank & Rural & Rank & Urban & Rank \\
\hline 1 & Shirala & 0.722 & 2 & 0.722 & 2 & - & \\
\hline 2 & Walwa & 0.743 & 1 & 0.743 & 1 & 0.502 & 1 \\
\hline 3 & Palus & 0.506 & 4 & 0.506 & 4 & - & - \\
\hline 4 & Kadegaon & 0.512 & 3 & 0.512 & 3 & - & - \\
\hline 5 & Khanapur & 0.501 & 5 & 0.502 & 5 & 0.498 & 2 \\
\hline 6 & Atpadi & 0.454 & 9 & 0.454 & 10 & - & - \\
\hline 7 & Tasgaon & 0.498 & 6 & 0.499 & 6 & 0.493 & 4 \\
\hline 8 & Miraj & 0.494 & 7 & 0.490 & 7 & 0.496 & 3 \\
\hline 9 & K. Mahankal & 0.470 & 8 & 0.470 & 8 & - & - \\
\hline 10 & Jat & 0.410 & 10 & 0.410 & 9 & - & - \\
\hline \multicolumn{2}{|c|}{ Sangli District } & 0.487 & - & 0.483 & - & 0.497 & - \\
\hline
\end{tabular}

Source: Authors Calculation/ From Table-6 tol0

Figure - 06

Tehsil \& Sector -wise Bear Necessity Index (BNI) of Sangli District

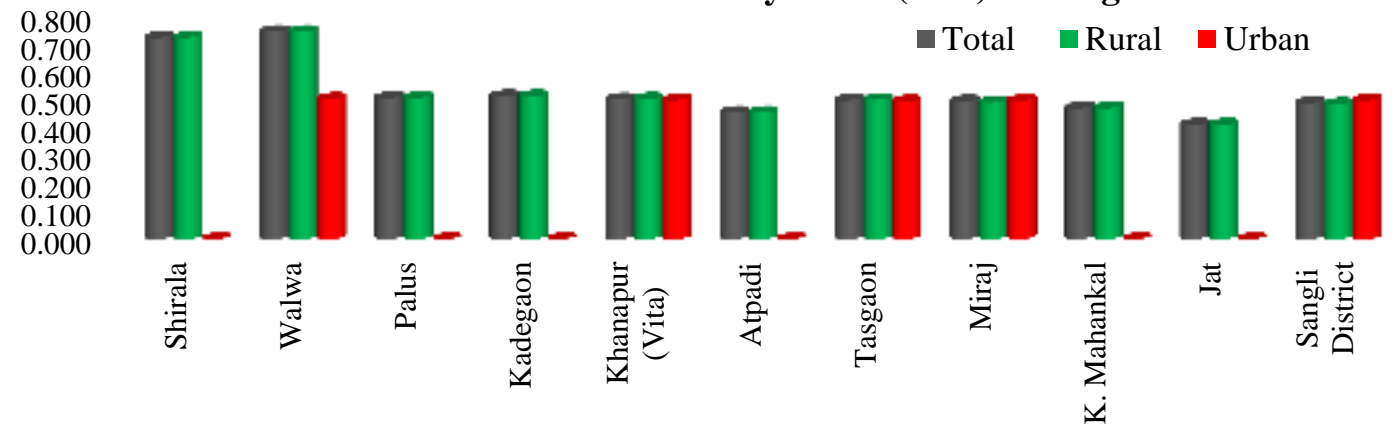

Table-11\& Fig. 06 provides information with respect to tehsils and sector-wise Bare Necessities Index (BNI) of Sangli district across the ten tehsils. The Bare Necessities Index (BNI) is grouped into three categories, which indicates that high Bare Necessities Index (BNI) has high access of bare necessities, the medium has a medium, and very low has very low respectively. Looking at tehsil and sector-wise Bare Necessities Index (BNI) of Sangli district, the Walwa total, rural and urban has been calculated $0.743,0.743$ and 0.502 respectively, it all higher and is ranked $1^{\text {st }}$ as compared to ten tehsils, except Walwa urban it all i.e., total and rural BNI comes under high category. Followed by Shirala total and rural has been noted at 0.722 singly, which all under high category and ranked $2^{\text {nd }}$ in Sangli district. While Jat total and rural has counted 0.410 individually, it comes under very low category, both ranked $10^{\text {th }}$ as well as very low as compared to ten tehsils. Observing the overall improvement in Bare Necessities Index (BNI) of Sangli district total, urban and rural has been counted nearly $0.487,0.483$ and 0.497 respectively, it all arises under very low category. But the BNI of Sangli urban is recorded higher than total as well as rural areas. Shortly, according to estimated Bare Necessities Index (BNI) of Sangli district except Shirala and Walwa all tehsils along with whole Sangli district, access of bare necessities to people is very low or medium. But sector-wise BNI is specifies that the access of bare necessities to urban people is higher than total as well as rural people in the Sangli district.

\section{FINDINGS}

The present section deals with important findings and some observations of this study, which is based on estimated Bare Necessities Index of Sangli district at tehsils with sectorial across twelve tehsils. The major findings and observations of this study are as follow-

1. Bare Necessities Index of Walwa total, rural and urban recorded highest access of bare necessities to total people, as compared to ten tehsils along with whole Sangli district.

2. Bare Necessities Index of Jat total, Atpadi rural and Tasgaon urban have lowest access of bare necessities to the people, as compared to ten tehsils of Sangli district.

3. Bare Necessities Index of Sangli district rural noted lowest as compared to urban, it indicates the access of bare necessities to rural people, is lower than urban people in Sangli district. 


\section{International Journal of Southern Economic Light (JSEL)}

- Peer Review Journal

4. Bare Necessities Index of whole Sangli district total has calculated very low category, hence it treated very low access of bare necessities or facilities to people in Sangli district.

\section{CONCLUSION}

People's efficiency to access basic requisites such as clean water, good housing, sanitation, electricity, and clean cooking fuel, etc., has a vital phase for the fulfillment of basic wants of individuals, to boost their normal of living and promote economic development as well as self-development. Accordingly, the estimation of Bare Necessities Index, of Sangli district except Shirala and Walwa most of the tehsils consist rural-urban have recorded very low or medium category. Whole Bare Necessities Index of Sangli district has recorded under the very low category including rural and urban area, but urban BNI is higher than rural as well as total. Hence, it indicates that except Shirala and Walwa, all tehsils along with rural and urban area the access of bare necessities to the people is very low or medium. But according to the sectorial evaluation of BNI, the access of bare necessities to rural people is lower than urban people, it retails sectorial inequalities between rural and urban people to access bare necessities in Sangli district.

\section{REFERENCES}

1. Census (2011), Census of India, 2011.

2. Census (2011), District Census Hand-Book/ Sangli District, 2011.

3. GOI (2021), Economic Survey of India- 2020-21, Department of Finance and Statistics, Government of India, Vol-1, New Delhi, 2021.

4. Nanaware D. R. and Kumbhar A. D. (2021), Sectorial Inequalities in Bare Necessities Index (BNI) of Solapur District: A Comparative Analysis, EPRA_International Journal of Indian Economic Light, (IJEL), Vol-9 \& Issue-1, May 2021.

5. Nanaware D. R. and Kumbhar A. D. (2021), Sectorial Inequalities in Access of Bare Necessities in Kolhapur District: A Comparative Analysis, EPRA_International Journal of Global Economic Light (JGEL), Vol-7 \& Issue-21, June, 2021.

6. Nanaware D. R., (2020), 'Social Inequalities in Household Infrastructure Development: A Case Study of Solapur District in Maharashtra', EPRA_International Journal of Research and Development (IJRD), VOL-5, Issue-3, 2020.

7. UNDP (2018), 'Human Development Technical Notes - 2019, United Nations Development Programme (UNDP), New York, 2019.

\section{WEBSITES}

1. http://www.censusindia.gov.in

2. https://www.indiabudget.gov.in/economicsurvey/

3. http://hdr.undp.org/en

4. www.maharashtra.gov.in

5. https://sangli.nic.in/ 